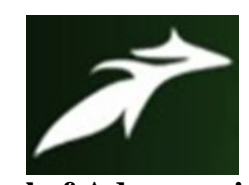

Amit Kumar et al, International Journal of Advances in Agricultural Science and Technology, Vol.8 Issue.8, August-2021, pg. 1-15

ISSN: 2348-1358

Impact Factor: 6.057

NAAS Rating: 3.77

\title{
AWARENESS OF THE RESPONDENTS TOWARDS ACTIVITIES OF CO-OPERATIVE SOCIETY IN PATNA DISTRICT OF BIHAR
}

\author{
Amit Kumar $^{1}$; Dipak Kumar Bose ${ }^{2}$, Jahanara ${ }^{3}$; Saloni Sarraf ${ }^{4}$ \\ ${ }^{1}$ M.Sc. Ag. (Agricultural Extension and communication), SHUATS (Prayagraj) \\ ${ }^{2}$ Associate Professor, Department of Agriculture Extension and Communication, SHUATS (Prayagraj) \\ ${ }^{3} \mathrm{Head}$, Department of Agriculture Extension and Communication, SHUATS (Prayagraj) \\ ${ }^{4}$ M.Sc. Ag. (Agricultural Extension and communication), SHUATS (Prayagraj) \\ Author's e-mail: irctcamit213@gmail.com \\ DOI: 10.47856/ijaast.2021.v08i8.001
}

\begin{abstract}
Agriculture being the backbone of Indian economy also acts as the core of Bihar's economy, employing 77 per cent of the work force and generating 35 per cent of the state domestic product. Meanwhile, the modernization and improvement of agriculture needs considerable investment. Whereas, Indian agriculture remained as poor man's occupation institutional credit plays an important role in agricultural development. Thus, Agricultural Credit Societies (PACS) provide cheaper credit to agriculture. Descriptive research design is adopted. 120 respondents from Baruna, Chipra and Faziabad in Sampatchak block of Patna district in Bihar was purposively selected for the study since it had more number of co-operative society are present as compared to others. The primary data were collected with the help of interview schedule and the responses were recorded, classified and tabulated and appropriate statistical tools were employed. The results indicated that 48.33 per cent of the respondents were aware of the functions of the co-operative society and 45 per cent of the respondents opined that the cooperative society performance was average in marketing of agricultural products. It also implied that rules, regulations and laws should be enacted and standardized for better regulation of cooperative societies.
\end{abstract}

Keywords: Co-operative society, Awareness level, Respondents 


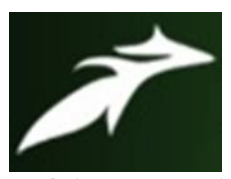

Amit Kumar et al, International Journal of Advances in Agricultural Science and Technology, Vol.8 Issue.8, August-2021, pg. 1-15

ISSN: 2348-1358

Impact Factor: 6.057

NAAS Rating: 3.77

\section{Introduction}

Eighty five percent of Indian population live in rural areas and depend on agriculture for necessities and as a source of employment (Negatu, et al., 2016). The success or failure of agriculture depends on the availability of finance. Whereas, Indian farmers don't have sufficient funds of their own to carry out their agricultural operations. In rural areas of India, credit requirements are more pressing as Indian population are mainly composed of small and marginal agricultural farmers, tenant cultivators, artisans and landless labor. Meanwhile, one of the popular but controversial agricultural development strategies is the establishment of agricultural cooperatives (Naghizadeh, 1984). Co-operative society in rural areas follows the principle of mutual help and self-help to attain the objective of rural development.

A co-operative society is a voluntary organization, which is established by an economically weak person for the betterment and upliftment of their economic condition through mutual help. It is legal entity and managed based on the democratic principle "One man, one vote". Primary agricultural credit society in villages are concentrating on providing cheap credit, but for the real benefit of farmer the co-operative should paves the way for repayment of credit by increasing his income. Eva Mondal (2020) mentioned that co-operative organizations help in availing loans at reasonable interest rates and reduces the chances of falling into a debt-trap. It also helps in procuring and providing manure, seeds, pesticides and other agricultural implements to the farmers which helps to solve many problems related to availability and procurement of inputs by small farmers.

Meanwhile, Dashmeet Kaur (2019) indicated that the central motive of the cooperative societies is to serve the needs of underprivileged and rural sections of our community. In addition to this, they mentioned that, an essential role of co-operative society's contribution lies in the advancement of villages. It is like a non-profit organization where every member joins a co-operative society to provide support instead of earning profits. In simply, co-operative 


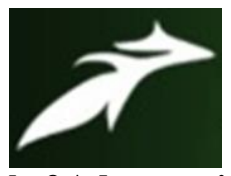

Amit Kumar et al, International Journal of Advances in Agricultural Science and Technology, Vol.8 Issue.8, August-2021, pg. 1-15

ISSN: 2348-1358

Impact Factor: 6.057

NAAS Rating: 3.77

society is based on 'all for each and each for all'. The main objective of the co-operative society was to save poor people providing goods at a lower price from the market price and eliminate the middle man and supply better services to its members.

Sahoo et.al., (2020) commented that cooperative societies have potential to act as not only financing credit in short term and medium term loan rather these can provide technical and vocational service to the small and marginal farmers to transform agriculture into agribusiness enterprise by pooling of the resource for realizing economies of scale. He also mentioned that mentioned that co-operative societies helps in agricultural development supporting critical inputs supply (seeds, fertilizer, pesticides, credit), storage facilities like Go-downs, agro-processing facilities and marketing the agro-produce. Mhembwe and Dube (2017) concluded that cooperatives play a significant role in defining and sustaining the lives of the communities. Therefore, rural communities have a lot to benefit from undertaking cooperative programmes.

\section{Statement of the problem}

Nowadays, agriculture has been modernized, which in turn requires considerable investment. But, in reality, Indian farmers being poor, small and marginal rely on external financial resources. Thus, to provide credit to farmers in cheaper rate of interest, Primary Agriculture Co-operative Societies paves the way. Hence, to make use of co-operative societies, there should be enough knowledge on the role and impact of co-operative society. With this background, the present study was conducted with the following objectives:

- To assess the socio-economic profiles of respondents

- To assess the awareness level on co-operative society among the respondents

- To analyse the association between socio-economic profile and awareness level 


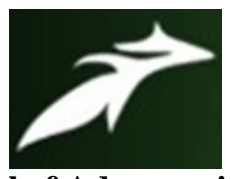

Amit Kumar et al, International Journal of Advances in Agricultural Science and Technology, Vol.8 Issue.8, August-2021, pg. 1-15

ISSN: 2348-1358

Impact Factor: 6.057

NAAS Rating: 3.77

\section{Methodology}

Descriptive research design is adopted for the study since it involves observing and describing the behaviour of the subject without influencing it in anyway. Patna district of Bihar was purposively selected for the study since it had more number of co-operative society are present as compared to other districts. In Patna district of Bihar, there are twenty three blocks, in which Sampatchak block is selected purposively since there are maximum number of cooperative societies as compared to other blocks. In Sampatchak block, there are 7 villages. Out of which 3 villages were selected purposively which had maximum number of co-operatives namely Baruna, Chipra and Faziabad. From each village, 40 respondents were selected; thus, 120 respondents were selected from the 3 villages. The primary data were collected with the help of interview schedule and the responses were recorded, classified and tabulated and appropriate statistical tools were employed and the results were presented as follows.

\section{Results and Discussion}

The socio-economic profile of the respondents were studied under various characteristics and the results were presented under table.1.

Table.1. Socio-economic profile of the respondents $(n=120)$

\begin{tabular}{|c|c|c|c|c|}
\hline S. No. & Characteristics & Category & Frequency & Percentage \\
\hline \multirow{2}{*}{1} & Age (in years) & Young $(<35)$ & 16 & 13.33 \\
\cline { 3 - 4 } & & Middle(36-55) & 82 & 68.34 \\
\cline { 3 - 4 } & & Old (>55) & 22 & 18.33 \\
\hline \multirow{2}{*}{2} & \multirow{2}{*}{ Education } & Illiterate & 28 & 23.33 \\
\cline { 3 - 4 } & & Primary & 21 & 17.50 \\
\cline { 3 - 5 } & & Matriculation & 12 & 10 \\
\cline { 3 - 5 } & & Secondary & 22 & 18.33 \\
\cline { 3 - 5 } & & Higher Secondary & 24 & 20.00 \\
\cline { 3 - 5 } & & Graduate and above & 8 & 6.67 \\
\hline
\end{tabular}




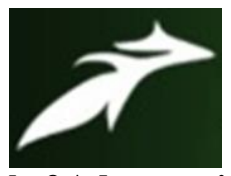

Amit Kumar et al, International Journal of Advances in Agricultural Science and Technology, Vol.8 Issue.8, August-2021, pg. 1-15

ISSN: 2348-1358

Impact Factor: 6.057

NAAS Rating: 3.77

\begin{tabular}{|c|c|c|c|c|}
\hline & & Diploma & 5 & 4.17 \\
\hline \multirow[t]{4}{*}{3} & \multirow[t]{4}{*}{ Occupation } & Agriculture & 38 & 31.67 \\
\hline & & Agriculture +Services & 8 & 6.67 \\
\hline & & Agriculture +Labour & 45 & 37.50 \\
\hline & & Agriculture + Business & 29 & 24.17 \\
\hline \multirow[t]{2}{*}{4} & \multirow[t]{2}{*}{ Family type } & Nuclear family & 67 & 55.83 \\
\hline & & Joint family & 53 & 44.17 \\
\hline \multirow[t]{3}{*}{5} & \multirow[t]{3}{*}{ Family size } & Small & 67 & 55.83 \\
\hline & & Medium & 28 & 23.34 \\
\hline & & Large & 25 & 20.83 \\
\hline \multirow[t]{3}{*}{6} & \multirow[t]{3}{*}{ Land holding } & $<2.5$ acres & 76 & 63.33 \\
\hline & & $2.5-5$ acres & 28 & 23.33 \\
\hline & & $>5$ acres & 16 & 13.33 \\
\hline \multirow[t]{3}{*}{7} & \multirow[t]{3}{*}{ Annual income } & Low (upto 50,000) & 27 & 22.50 \\
\hline & & Medium $(50,000-1$ lakh $)$ & 56 & 46.67 \\
\hline & & High ( above 1 lakh) & 37 & 30.83 \\
\hline \multirow[t]{3}{*}{8} & \multirow[t]{3}{*}{ Mass media exposure } & Low & 37 & 30.83 \\
\hline & & Medium & 59 & 49.17 \\
\hline & & High & 24 & 20.00 \\
\hline \multirow[t]{3}{*}{9} & \multirow{3}{*}{$\begin{array}{l}\text { Credit sources to } \\
\text { agriculture }\end{array}$} & Commercial bank & 34 & 28.33 \\
\hline & & PACS & 65 & 54.17 \\
\hline & & Private money lenders & 21 & 17.50 \\
\hline \multirow[t]{3}{*}{10} & \multirow[t]{3}{*}{ Social participation } & Low & 24 & 20.00 \\
\hline & & Medium & 54 & 45.00 \\
\hline & & High & 42 & 35.00 \\
\hline \multirow[t]{3}{*}{11} & \multirow[t]{3}{*}{ Extension contact } & Low & 45 & 37.50 \\
\hline & & Medium & 47 & 39.17 \\
\hline & & High & 28 & 23.33 \\
\hline \multirow[t]{3}{*}{12} & \multirow[t]{3}{*}{ Experience in farming } & Less than 3 years & 14 & 11.67 \\
\hline & & $3-10$ years & 76 & 63.33 \\
\hline & & More than 10 years & 30 & 25.00 \\
\hline
\end{tabular}




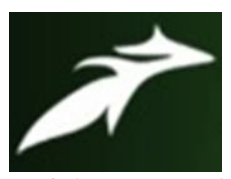

Amit Kumar et al, International Journal of Advances in Agricultural Science and Technology, Vol.8 Issue.8, August-2021, pg. 1-15

ISSN: 2348-1358

Impact Factor: 6.057

NAAS Rating: 3.77

From table.1, it can be understand that majority of the respondents belonged to middle age $(68.34 \%)$, followed by old $(18.33 \%)$ and young $(13.33 \%)$. This might be because of middle aged people had more responsibilities to earn for their family. Majority of the respondents were literate, of which higher secondary (20\%), secondary (18.33\%), primary (17.50\%), matriculation (10\%), graduate and above (6.67\%), diploma (4.17\%) and some of them $(10 \%)$ were illiterate. This might be because of the increasing awareness on education. Most of the respondents were doing agriculture + labor as their occupation (37.50\%), followed by agriculture (31.67\%), agriculture + services (6.67\%) and agriculture + business $(4.16 \%)$. This might be because of their profession by nature.

More than half of the respondents had nuclear family $(55.83 \%)$, followed by joint family (44.17\%). This is because the respondents had migrated from their native for living. Most of the respondents possessed small family (55.83\%), followed by medium (23.34\%) and large $(20.83 \%)$. This is because of the preference of the respondents. Nearly half of the respondents had medium level of annual income (46.67\%), followed by high (30.83\%) and low (22.50\%) level of annual income. This might be because of their job or work nature. More than half of the respondents consider co-operative society as the credit source to agriculture $(54.17 \%)$, followed by commercial banks $(28.33 \%)$ and private money lenders $(17.50 \%)$. This is because of the cheaper or least interest provided by the co-operative society.

Nearly half of the respondents had medium level of mass media exposure $(49.17 \%)$, followed by low (30.83\%) and high (20\%). This might be because of the respondents were aware of the benefits of the mass media for immediate update of news and more details \& contacts obtained through mass media. Nearly two-third of the respondents (63.33\%) had less than 2.5 acres, followed by 23.33 per cent of the respondents had a land holding of $2.5-5$ acres and 13.33 per cent of the respondents had a land holding of more than 5 acres. This is because of the possession of agricultural land by the respondent by earning or inheritance. Most of the respondents had medium level of extension contact (39.17\%), followed by low (37.50\%) and 


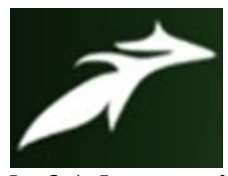

Amit Kumar et al, International Journal of Advances in Agricultural Science and Technology, Vol.8 Issue.8, August-2021, pg. 1-15

ISSN: 2348-1358

Impact Factor: 6.057

NAAS Rating: 3.77

high $(23.33 \%)$ level of extension contact. This might be because of the fact that members and board directors are in contact with extension agents to manage their institution.

Nearly half of the respondents had medium level of social participation (45\%), followed by high (35\%) and low (20\%) level of social participation. This might be because of the respondent's involvement or participation in the organization. Nearly two-third of the respondents $(63.33 \%)$ had 3-10 years of experience in farming, followed by 25 per cent had more than 10 years of experience and only few (11.67\%) had less than 3 years of experience in farming. This might be because of the fact possession of agricultural land by inheritance and also because of agriculture and agricultural labor as their occupation.

The awareness level of respondents on co-operative society has been recorded, categorized and presented in table.2.

Table.2. Distribution of respondents based on their awareness level on co-operative society

$(\mathbf{n}=\mathbf{1 2 0})$

\begin{tabular}{|c|c|c|c|c|}
\hline \multirow{2}{*}{$\begin{array}{l}\text { S. } \\
\text { No. }\end{array}$} & \multirow[t]{2}{*}{ Statements } & \multirow[t]{2}{*}{ Category } & \multicolumn{2}{|c|}{ Response } \\
\hline & & & Frequency & Percent \\
\hline \multirow[t]{2}{*}{1} & \multirow{2}{*}{$\begin{array}{l}\text { Are you a member of the co-operative } \\
\text { society in your village }\end{array}$} & Yes & 89 & 74.17 \\
\hline & & No & 31 & 25.83 \\
\hline \multirow[t]{2}{*}{2} & \multirow{2}{*}{$\begin{array}{l}\text { Have you obtained any loan from co- } \\
\text { operative society }\end{array}$} & Yes & 116 & 96.67 \\
\hline & & No & 4 & 3.33 \\
\hline \multirow[t]{3}{*}{3} & \multirow[t]{3}{*}{ Purpose of taking loan } & Buying agriculture land & 23 & 19.16 \\
\hline & & $\begin{array}{l}\text { Construction of } \\
\text { building }\end{array}$ & 8 & 6.67 \\
\hline & & $\begin{array}{l}\text { Purchase of fertilizers } \\
\text { seeds }\end{array}$ & 21 & 17.50 \\
\hline & & & & \\
\hline
\end{tabular}




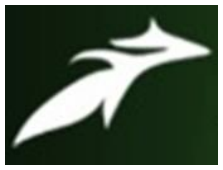

Amit Kumar et al, International Journal of Advances in Agricultural Science and Technology, Vol.8 Issue.8, August-2021, pg. 1-15

ISSN: 2348-1358

Impact Factor: $\mathbf{6 . 0 5 7}$

NAAS Rating: 3.77

\begin{tabular}{|c|c|c|c|c|}
\hline & & $\begin{array}{l}\text { Purchase of agricultural } \\
\text { implements }\end{array}$ & 38 & 31.66 \\
\hline & & $\begin{array}{l}\text { Purchase of cattle's / } \\
\text { animal }\end{array}$ & 24 & 20.00 \\
\hline & & Marriage purpose & 6 & 5.00 \\
\hline \multirow[t]{2}{*}{4} & \multirow{2}{*}{$\begin{array}{l}\text { Will you repay the loan within specific } \\
\text { time period }\end{array}$} & Yes & 83 & 69.16 \\
\hline & & No & 37 & 30.83 \\
\hline \multirow[t]{4}{*}{5} & \multirow{4}{*}{$\begin{array}{l}\text { Which commodities are supplied by } \\
\text { the society }\end{array}$} & Stationary & 2 & 1.67 \\
\hline & & Cloth & 2 & 1.67 \\
\hline & & Sugar & 35 & 29.17 \\
\hline & & Kerosene & 81 & 67.50 \\
\hline \multirow[t]{6}{*}{6} & \multirow{6}{*}{$\begin{array}{l}\text { In your opinion, what is the reason for } \\
\text { slow recovery of loan by the society }\end{array}$} & Poverty & 4 & 3.33 \\
\hline & & Use of consumption & 60 & 50.00 \\
\hline & & No additional income & 19 & 15.83 \\
\hline & & Carelessness & 3 & 2.50 \\
\hline & & Natural calamities & 17 & 14.16 \\
\hline & & Unrenumeration price & 17 & 14.16 \\
\hline \multirow[t]{4}{*}{7} & \multirow{4}{*}{$\begin{array}{l}\text { Which agricultural inputs are supplied } \\
\text { by the co-operative society }\end{array}$} & Fertilizerrs & 84 & 70.00 \\
\hline & & Seeds & 19 & 15.83 \\
\hline & & Diesel & 0 & 0 \\
\hline & & Oil & 17 & 14.16 \\
\hline \multirow[t]{2}{*}{8} & \multirow{2}{*}{$\begin{array}{l}\text { Establishment of society increases the } \\
\text { agricultural productivity as a supply of } \\
\text { credit }\end{array}$} & Yes & 72 & 60.00 \\
\hline & & No & 48 & 40.00 \\
\hline \multirow[t]{2}{*}{9} & \multirow{2}{*}{$\begin{array}{l}\text { Membership in co-operative society } \\
\text { increases the status in society }\end{array}$} & Yes & 87 & 72.50 \\
\hline & & No & 33 & 27.50 \\
\hline
\end{tabular}




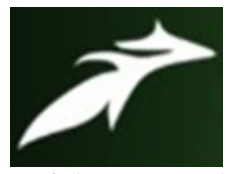

Amit Kumar et al, International Journal of Advances in Agricultural Science and Technology, Vol.8 Issue.8, August-2021, pg. 1-15

ISSN: 2348-1358

Impact Factor: $\mathbf{6 . 0 5 7}$

NAAS Rating: 3.77

\begin{tabular}{|c|c|c|c|c|}
\hline \multirow[t]{2}{*}{10} & \multirow{2}{*}{$\begin{array}{l}\text { Co-operative society helps to solve the } \\
\text { problems in agricultural development }\end{array}$} & Yes & 83 & 69.17 \\
\hline & & No & 37 & 30.83 \\
\hline \multirow[t]{2}{*}{11} & \multirow{2}{*}{$\begin{array}{l}\text { Co-operative societies increase the } \\
\text { social responsibility of an individual in } \\
\text { society }\end{array}$} & Yes & 66 & 55.00 \\
\hline & & No & 54 & 45.00 \\
\hline \multirow[t]{2}{*}{12} & \multirow{2}{*}{$\begin{array}{l}\text { Whether co-operative society is well } \\
\text { managed by the elected board }\end{array}$} & Yes & 91 & 75.83 \\
\hline & & No & 29 & 24.17 \\
\hline \multirow[t]{2}{*}{13} & \multirow{2}{*}{$\begin{array}{l}\text { Does co-operative society promote } \\
\text { unity and solidarity among the } \\
\text { members and beneficiaries of the } \\
\text { society }\end{array}$} & Yes & 43 & 35.83 \\
\hline & & No & 77 & 64.17 \\
\hline \multirow[t]{2}{*}{14} & \multirow{2}{*}{$\begin{array}{l}\text { Whether weaker section people are } \\
\text { empowered through co-operative } \\
\text { society }\end{array}$} & Yes & 73 & 60.83 \\
\hline & & No & 47 & 39.17 \\
\hline \multirow[t]{2}{*}{15} & \multirow{2}{*}{$\begin{array}{l}\text { Why people in society prefer co- } \\
\text { operative society than commercial } \\
\text { bank for getting credit }\end{array}$} & Lesser interest & 61 & 50.83 \\
\hline & & Subsidy & 59 & 49.17 \\
\hline \multirow[t]{2}{*}{16} & \multirow{2}{*}{$\begin{array}{l}\text { Whether members or beneficiaries of } \\
\text { society are empowered financially by } \\
\text { the co-operative society }\end{array}$} & Yes & 86 & 71.67 \\
\hline & & No & 34 & 28.33 \\
\hline \multirow[t]{2}{*}{17} & \multirow{2}{*}{$\begin{array}{l}\text { Whether co-operative society enhances } \\
\text { the leadership skills }\end{array}$} & Yes & 54 & 45.00 \\
\hline & & No & 66 & 55.00 \\
\hline \multirow[t]{2}{*}{18} & \multirow{2}{*}{$\begin{array}{l}\text { Does co-operative society increase the } \\
\text { monthly income of an member or a } \\
\text { beneficiary }\end{array}$} & Yes & 47 & 39.17 \\
\hline & & No & 73 & 60.83 \\
\hline
\end{tabular}




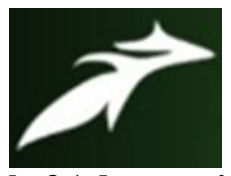

Amit Kumar et al, International Journal of Advances in Agricultural Science and Technology, Vol.8 Issue.8, August-2021, pg. 1-15

ISSN: 2348-1358

Impact Factor: 6.057

NAAS Rating: 3.77

\begin{tabular}{|c|c|c|c|c|}
\hline \multirow[t]{2}{*}{19} & \multirow{2}{*}{$\begin{array}{l}\text { Whether co-operative society provides } \\
\text { agricultural training activities }\end{array}$} & Yes & 15 & 12.50 \\
\hline & & No & 105 & 87.50 \\
\hline \multirow[t]{2}{*}{20} & \multirow{2}{*}{$\begin{array}{l}\text { Whether co-operative society guides } \\
\text { the members and beneficiaries for } \\
\text { utilization of loan }\end{array}$} & Yes & 108 & 90.00 \\
\hline & & No & 12 & 10.00 \\
\hline \multirow[t]{4}{*}{21} & \multirow[t]{4}{*}{ How often you visit the society } & Rabi and Kharif & 33 & 27.50 \\
\hline & & Monthly & 72 & 60.00 \\
\hline & & Quarterly & 15 & 12.50 \\
\hline & & Never & 0 & 0.00 \\
\hline \multirow[t]{2}{*}{22} & \multirow{2}{*}{$\begin{array}{l}\text { Whether you society possess variety of } \\
\text { fertilizers }\end{array}$} & Yes & 45 & 37.50 \\
\hline & & No & 75 & 62.50 \\
\hline \multirow[t]{2}{*}{23} & \multirow{2}{*}{$\begin{array}{l}\text { Do you face any difficulties in availing } \\
\text { benefit from the society }\end{array}$} & Yes & 32 & 26.67 \\
\hline & & No & 88 & 73.33 \\
\hline
\end{tabular}

From table. 2 it can be interpreted that 74.17 percentage agrees that they are member of the co-operative society and 25.83 percentage denies it. 96.67 percentage obtained loan from co-operative society and 3.33 percentage not obtained loan. 31.67 percentage obtain loan for purchase of agricultural implements, 20 percentage obtain loan for purchasing cattle or animal,19.16 percentage for buying agricultural land, 17.50 percentage for purchase of fertilizers seeds, 6067 percentage for building construction and 5 percentage for marriage purpose. 69.16 percentage of the respondents agree that they will repay the loan in specific time period, 30.83 percentage denies it. 67.50 percentage of the respondents mentioned that kerosene is supplied by the society, sugar $(29.17 \%)$, cloth $(1.67 \%)$ and stationary $(1.67 \%)$ respectively are the commodities supplied by the society.

Meanwhile, half of the respondents felt that loan used for consumption purpose is the slow recovery of loan by the society (50\%), 15.83 percentage as no additional income, an equal 


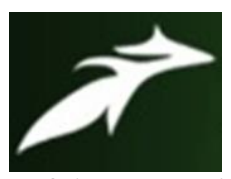

Amit Kumar et al, International Journal of Advances in Agricultural Science and Technology, Vol.8 Issue.8, August-2021, pg. 1-15

ISSN: 2348-1358

Impact Factor: 6.057

NAAS Rating: 3.77

percentage of respondents felt that natural calamities (14.16\%) and unremuneration price $(14.16 \%)$ and carelessness $(2.50 \%)$ are the reasons for slow recovery. 70 percentage of the respondents felt that fertilizers, 15.83 percentage felt that seeds and 14.16 percentage felt that oil is supplied by the co-operative society. 60 percentage of the respondents agrees that the establishment of the society increase the agricultural productivity as a supply of credit and 40 percentage denies it. 72.50 percentage of the respondents felt that membership in co-operative society increases the status in society and 27.50 percentage of respondents denies it.

Similarly, 69.17 percentage of the respondents felt that co-operative helps to solve the problems in agricultural development, and 30.83 percentage denies it. 55 percentage of the respondents agrees that co-operative societies increases the social responsibility of an individual in society and 45 percentage denies it. 75.83 percentage of the respondents agrees that coperative society is well managed by the elected board and 24.17 percentage denies it. 64.17 percentage of the respondents felt that co-operative society promote unity and solidarity among the members and beneficiaries of the society and 35.83 percentage denies it. 60.83 percentage of the respondents felt that weaker sections people are empowered through co-operative society and 39.17 percentage denies it.

More than half of the respondents felt that lesser interest (50.83\%) and subsidy (49.17\%) are the reasons for which people preferred co-operative society than commercial bank for getting credit. 71.67 percentage of the respondents felt that members or beneficiaries are empowered financially by the co-operative society (28.33\%). 55 percentage of the respondents felt that co-operative society enhance the leadership skills and 45 percentage felt that it doesn't. 60.83 percentage of the respondents felt that co-operative doesn't increase the monthly income of an member of a beneficiary and 39.17 percentage denies it. 87.50 percentage of the respondents felt that co-operative society provides agricultural training activities and 12.50 percentage denies it. 


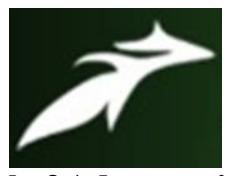

Amit Kumar et al, International Journal of Advances in Agricultural Science and Technology, Vol.8 Issue.8, August-2021, pg. 1-15

ISSN: 2348-1358

Impact Factor: 6.057

NAAS Rating: 3.77

Meanwhile, 90 percentage of the respondents felt that co-operative society guides the members and beneficiaries for utilization of loan and 10 percentage denies it. 60 percentage agrees that farmers visit society during monthly, 27.50 percentage during rabi and kharif and 12.50 percentage during quarterly. 62.50 percentage felt that society possess variety of fertilizers and 37.50 percentage denies it. 73.33 percentage mentioned that they didn't face any difficulties in availing benefit from the society and 26.67 percentage agrees that they face difficulties.

The overall awareness level of respondents on co-operative society has been recorded, categorized and presented in table.3.

Table.3. Distribution of respondents based on their overall awareness level on co-operative society

$(\mathbf{n}=\mathbf{1 2 0})$

\begin{tabular}{|c|c|c|c|}
\hline S. No. & Awareness level & Frequency & Percentage \\
\hline 1 & Low & 7 & 5.84 \\
\hline 2 & Medium & 58 & 48.33 \\
\hline 3 & High & 55 & 45.83 \\
\hline
\end{tabular}

From table.3, it can be understood that majority of the respondents were aware of the co-operative society; out of which 48.33 percentage were medium level aware, 45.83 percentage were high level aware and only few (5.84\%) were less aware of co-operative society. This indicates the involvement of the respondents in the co-operative society.

The relationship between socio-economic characteristics and awareness level of respondents on co-operative society on agriculture society was studied and the results were presented in table.4. 


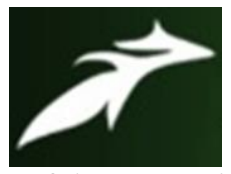

Amit Kumar et al, International Journal of Advances in Agricultural Science and Technology, Vol.8 Issue.8, August-2021, pg. 1-15

ISSN: 2348-1358

Impact Factor: 6.057

NAAS Rating: 3.77

Table.4. Association between the socio-economic characteristics and awareness level of respondents on co-operative society on agricultural development

\begin{tabular}{|c|c|c|c|c|c|}
\hline $\begin{array}{l}\text { S. } \\
\text { No. }\end{array}$ & Characteristics & 'r' value & $\begin{array}{l}\text { Regression } \\
\text { co-efficient }\end{array}$ & $\begin{array}{c}\text { Standard } \\
\text { error }\end{array}$ & t-value \\
\hline $\mathrm{X}_{1}$ & Age & $0.085^{\mathrm{NS}}$ & 0.475 & 0.862 & $0.551^{\mathrm{NS}}$ \\
\hline $\mathrm{X}_{2}$ & Caste & $-0.0151^{\mathrm{NS}}$ & -0.334 & 1.405 & $-0.238^{\mathrm{NS}}$ \\
\hline $\mathrm{X}_{3}$ & Education & $0.646 * *$ & 6.270 & 0.864 & $7.253 * *$ \\
\hline $\mathrm{X}_{4}$ & Occupation & $0.101 * *$ & 0.221 & 0.094 & $2.345^{*}$ \\
\hline $\mathrm{X}_{5}$ & Annual Income & $0.620 * *$ & 0.853 & 0.417 & $2.047 *$ \\
\hline $\mathrm{X}_{6}$ & Social participation & $0.438 * *$ & $6.372 * *$ & 0.000 & $0.131 * *$ \\
\hline $\mathrm{X}_{7}$ & Size of land holding & $-0.055^{\mathrm{NS}}$ & $1.326^{*}$ & 0.596 & $0.031 *$ \\
\hline $\mathrm{X}_{8}$ & $\begin{array}{l}\text { Farm power } \\
\text { possession }\end{array}$ & $0.026^{\mathrm{NS}}$ & 0.537 & 1.043 & $0.515^{\mathrm{NS}}$ \\
\hline $\mathrm{X}_{9}$ & $\begin{array}{l}\text { Experience in } \\
\text { farming }\end{array}$ & $-0.047^{\mathrm{NS}}$ & -0.551 & 0.794 & $-0.694^{\mathrm{NS}}$ \\
\hline $\mathrm{X}_{10}$ & Mass media exposure & $0.297 * *$ & $3.863^{*}$ & 1.894 & $0.047 *$ \\
\hline $\mathrm{X}_{11}$ & $\begin{array}{l}\text { Sources of } \\
\text { agriculture credit }\end{array}$ & $0.252 * *$ & $3.465^{*}$ & 1.682 & $0.045^{*}$ \\
\hline
\end{tabular}




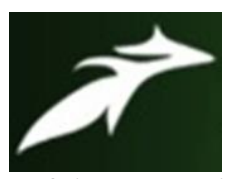

Amit Kumar et al, International Journal of Advances in Agricultural Science and Technology, Vol.8 Issue.8, August-2021, pg. 1-15

ISSN: 2348-1358

Impact Factor: 6.057

NAAS Rating: 3.77

\begin{tabular}{|c|l|c|c|c|c|}
\hline $\mathrm{X}_{12}$ & Extension contact & $0.307 * *$ & $2.519 *$ & 1.374 & $0.073 *$ \\
\hline
\end{tabular}

$R^{2}=\mathbf{0 . 5 3 5} \quad \mathrm{F}=\mathbf{5 . 0 6 4} \quad \mathrm{a}=\mathbf{1 5 1 . 6 7 7}$

NS $=$ Not Significant $; *=$ Significant at $5 \%, * *=$ Significant at $1 \%$.

From table.4, it can be interpreted that socio-economic characteristics like age and farm power possession had non-significant association with awareness level of respondents on co-operative society; caste and experience in farming had negative and non-significant association with awareness level of respondents on co-operative society on agricultural development. Meanwhile, education, occupation, annual income, social participation, mass media exposure, sources of agricultural credit, extension contact had positive and significant association with awareness level of respondents on co-operative society.

\section{Conclusion}

From the above study, it could be concluded that majority of the respondents belonged to middle age (68.34\%), illiterate $(23.33 \%)$, agriculture + labor as their occupation $(37.50 \%)$, nuclear family (55.83\%), medium level of annual income (46.67\%), mass media exposure (49.17\%), had less than 2.5 acres (63.3\%). Most of the respondents had medium level of extension contact (39.17\%), social participation (45\%), 48.33 percentage were medium level aware of the co-operative society. Socio-economic characteristics like age and farm power possession had non-significant association; caste and experience in farming had negative and non-significant association; education, occupation, annual income, social participation, , mass media exposure, sources of agricultural credit, extension contact had positive and significant association with awareness level of respondents on co-operative society.Though co-operatives provides inputs; they are not available at right time and it should ensure providing quality inputs. More capital should be provided to farmers at least interest rate. Storing of produce, transport and marketing facilities should be improvised. Staffs with technical knowledge, more co- 


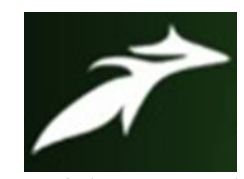

Amit Kumar et al, International Journal of Advances in Agricultural Science and Technology, Vol.8 Issue.8, August-2021, pg. 1-15

ISSN: 2348-1358

Impact Factor: 6.057

NAAS Rating: 3.77

operative in nature should be appointed. Rules, regulations and laws should be enacted and standardized for better regulation of co-operative societies.

\section{References}

[1]. Mondal, Eva. 2020. The Role of co-operatives in Agriculture sector.

https://www.indianfolk.com/role-cooperatives-agriculture-

sector/\#: :text=Co\%2Doperatives\%20also\%20help\%20in,of\%20inputs\%20by\%20small\%20farm ers.\&text=It\%20also\%20enhances\%20and\%20encourage\%20local\%20leadership\%20among\%20 the $\% 20$ farmer\%20communities

[2]. Kaur, Dashmeet. 2019. What is the Role of Co-operative Society in Rural Development?. https://swaritadvisors.com/learning/what-is-the-role-of-co-operative-society-in-rural-development/

[3]. Mhembwe S. \& Dube E. (2017). The role of cooperatives in sustaining the livelihoods of rural communities: The case of rural cooperatives in Shurugwi District, Zimbabwe, Journal of disaster risk studies. Jamba. 9(1): 341.Published online 2017 Apr 24.

[4]. Naghizadeh, Mohammad 1984 The Role of Farmer's Self-determination, Collective Action and Cooperatives in Agricultural Development: A Case Study of Iran. Tokyo (Japan): institute for the Study of Languages and Cultures of Asia and Africa.

[5]. Negatu B, Kromhout H, Mekonnen Y, Vermeulen R (2016) Use of chemical pesticides in Ethiopia: a cross-sectional comparative study on knowledge, attitude and practice of farmers and farm workers in three farming systems. Ann Occup Hyg 60(5):551-566.

[6]. Sahoo et al., (2020) Critical Review on Cooperative Societies in Agricultural Development in India,Current Journal of Applied Science and Technology. 39(22): 114-121, 2020; Article no.CJAST.59935 